\title{
Sexuality of the Person with Intellectual Disability as Health Education Practice
}

Gracimary Alves Teixeira", Jovanka Bittencourt Leite de Carvalho², Mércio Gabriel de Araújo", Flavio César Bezerra da Silva², Ana Cristina Araújo de Andrade Galvão², Fábia Barbosa de Andrade $^{3}$, Marília Rute de Souto Medeiros ${ }^{4}$, Luana Medeiros Silva Henrique ${ }^{4}$

\section{Abstract}

The person with mental disabilities suffer trouble dealing with themes geared to sexuality, as well as parents and health professionals feel insecure to discuss this matter.

Objective: Report on lived experience of the person with intellectual disabilities and their families about sexuality in the context of health education.

Method: An exploratory and descriptive study with approach anchored in the experience report. The study was conducted with users, parents and health professionals from an institution of care of people with a disability in the municipality of Santa Cruz-RN. The research was developed in the context of practical discipline of Primary Care and Family Health of undergraduate nursing degree from the Universidade federal do Rio Grande do Norte. It was used wheels of conversations and nursing consultations that allowed individual and collective reports.

Results: Previous knowledge concerning sexuality were rescued, allowing users to identify and reflect on stereotypes involving male and female behavior. The wheels of conversations and dynamic with parents and health professionals allowed to note: weaknesses of professionals to deal with issues that permeate the lives of people with disability intelecutal; as well as feelings and conceptions encompassing parents to discuss this theme.

Conclusion: Health education conducted favored to minimize the lack of knowledge and approach of health professionals to work with the theme of sexuality existent in the institution.
1 Nurse. Doctoral student at the Graduate of the Federal University of Rio Grande do Norte Program.

2 Nurse. PhD. Health School professor at the Federal University of Rio Grande do Norte.

3 Nurse. PhD. Professor of Graduate Nursing Faculty of Health Sciences Trairi/ Federal University of Rio Grande do Norte.

4 Nurse. Nursing Faculty of Health Sciences Trairi/ Federal University of Rio Grande do Norte.

Contact information:

Gracimary Alves Teixeira

ほ gracimaryalves@yahoo.com.br
Keywords
Health Education; Sexuality, Health Mental; Community Health Nursing. 


\section{Introduction}

Sexuality appears as a striking theme in education due to social, cultural and religious context that individuals have built throughout history. It becomes more delicate when this issue is dealt for people with intellectual disability because infant idealization is assigned to this group. Thus, Sexually Transmitted Diseases (STDs) and unplanned pregnancy are more likely to occur.

In area of mental health sexuality is permeated by invisibility and cloaking, even being present by gestures, body movements or in the speeches of users with mental disorders. Health professionals do not deal with this issue keeping it silent or covert in the practice of care. And when this theme comes up it is seen as a manifestation of mental illness, because professionals believe that users are unable to present feelings arising from a sexual relationship [1]

According to the World Health Organization (WHO), sexuality is a basic need that makes up the human being. Moreover, sexuality is undissociated to other aspects of life. It is noteworthy as being more than sexual act, meaning it is the energy that drives encounter for love, intimacy and contact, influencing the physical and mental health of individuals. Sexual health should be considered a basic human right, which involves several factors such as: body, history, personal relationships and the culture of the people. In addition, there are difficulties to openly discuss this matter, especially in the family environment when it involves children and young people [2].

That sense approach the topic sexuality is a challenge. For it health education emerges as a device that strengthens health practices to allow user participation in the construction and knowledge exchange. The educational practice should be understood as a producer of care and transformative both social and life contexts [3].

Health education is also understood as a resource through which the scientific knowledge produced reaches the daily life of the population. Thus, it will allow changes in the thinking and acting of people. It also facilitates to development of strategies to strengthen the co-participation of these individuals making them responsible for their change process [3].

The need to carry out an educational practice in care institution to the person with a mental disability, in the municipality of Santa Cruz, Rio Grande do Norte, occurred for two reasons. First, considering that users with mental disabilities suffer trouble dealing with themes focused on sexuality. Second, because parents and health professionals do not feel safe to discuss this topic.

It is hoped that this action minimize vulnerability of this public to prejudices about sexuality of the person with mental disabilities and risks of unsafe sex may result in unplanned pregnancy and STDs.

Thus, the study aims to relate the experience lived on the sexuality of people with mental disability and their families in the context of health education. It is noteworthy that the theoretical and methodological framework that health education is based on the National Curriculum Guidelines of Graduate Nursing [4].

\section{Method}

This is an exploratory and descriptive study with approach anchored in the experience report developed in a health institution of care to people with mental disabilities.. Health education was based on the curricular component context Primary Care and Family Health offered on the 5th period of undergraduate course in Nursing of Faculdade de Ciências da Saúde do Trairi (FACISA) da Universidade Federal do Rio Grande do Norte (UFRN).

This theme emerges from the need reported by health institutions professionals about sexuality of the person with mental disabilities and the interest mentioned by users of that service. Thus, there were educational activities directed to users, parents and professionals of this institution. 
Thus, the students of the curricular component mentioned above were included in this health institution of care to people with mental disabilities. The choice for this space occurred because it is a reference to people with physical and mental disability to Trairí region.

The institution serves 62 people with mental and physical disabilities, in morning and afternoon shi$\mathrm{fts}$. Participated in the activities 58 users, 32 parents, 06 members of the health institution staff, 41 nursing students and 01 nursing professor. The pedagogical tools used for achieving these actions were Education Workshops in Health and Communication. Besides these also used the reproductive rights Pad, sexual and contraceptive methods and Freire's method [5-7].

In this perspective it was developed five actions in the institution: knowing the singular reality of the institution; conducting wheels of conversation with users of the institution; Nursing consultations for people with mental disabilities; knowledge of parents, guardians and professionals of the institution about sexuality from wheels of conversation and; dynamic called 'Dynamics of boxes'. These activities were conducted in October and November 2013.

Initially, the students and docent conducted a previous visit, knowing the physical structure, working process of the multidisciplinary team to detect the demands of users. Then it was discussed topics focused on sexuality, contraception, pregnancy and STDs. Another activity was the realization of nursing consultations which allowed greater privacy for users to discuss issues of sexuality.

Finally occurred approach with parents, guardians and health professionals of the institution through wheels of conversation to identify the knowledge that these people had about sexuality and reproductive and sexual rights. For this, it was used dynamic 'Boxes of Knowledge' in the perspective of seek understanding from parents and service professionals about the importance of relationships established in people with mental disabilities.
The evaluation of the shares was made from photographic records and notes during activities. This material was analyzed after actions by health professionals of the institution, nursing students and docent who participated in the intervention.

\section{Results and Discussion}

The activities were initiated by means insertion of students in the institution aiming to know the reality, the working process of professionals and the activities and services provided to users with mental disabilities. It was noted that actions to improve the health conditions of its members are developed, but also promotes reintegration of these individuals in the community through services aimed at minimizing their limitations.

At the time of visit to the institution, health professionals reported the need for health education activities for people with mental disability, given the difficulties of the professionals working in this perspective. So, it was emerged sexuality as a theme to be approached to users.

Then, it was was sought to to discuss with people with mental disability the need to work the theme of sexuality, being evidenced by the research subjects interest in the topic. The obtained positive response may have been influenced by the public is composed mostly by teenagers and adults.

Parents and family members presented themselves constrained during initial approach of the students, being necessary to clarify relevance of discussing sexuality with users and with other participants. STDs and unplanned pregnancy are striking in the life of any human being and for people with mental disabilities this would be no different. In this respect parents are often absent in this discussion and not allow their children to express their doubts.

The difficulty of parental acceptance may be related to the low level of education and age above 60 years. These factors influence the opinions of these subjects because educational and cultural training 
they received hampers dialogue of parents about sexuality.

Discussion of sexuality is needed between parents and teens to broader view of the subject. This enables occurs incentive for condom use, preventing unplanned pregnancy and STDs/AIDS [8].

After being defined sexuality as a theme to be worked through health education a wheels of conversations involving people with mental disabilities was developed. For such action it was chosen a public square of the city featuring leafy, pleasant and relaxed atmosphere that allowed greater interaction among users/students/teacher. It was used as a creative and sensitive method, Freire's cultural circles, with spaces for discussion and reflection leading subject to problematize their experiential and existential practices [7].

In this sense, the wheels of conversations was guided by themes such as dating, contraception, pregnancy, STDs. The activity started with the students presenting contraceptive methods and the importance of their use. The dating was discussed with emphasis on quick relationships that are established between people, and the sexual act as an uncompromising practice. Regarding pregnancy, this was seen as the acquisition of a responsibility that needs to be planned and thought between the couple. And STDs have become an obvious subject on the non-use of condoms as effective for prevention.

Users demonstrated knowledge about sexuality issues. Despite this, there was difficulty in communication on the subject. From it was possible to identify the interest in the topic and that some users did not know the contraceptive methods. This activity provided an opportunity individual and collective stories, recovering the prior knowledge about the issues discussed. This experience has allowed users to identify and to reflect on stereotypes involving male and female behavior.

Lack of knowledge about some topics covered may be due to sex education offered by parents. It is noteworthy that parents can not just impose rules and regulations on family space. Parents should also welcome the changes that occur abroad, seeking to adapt to the demands made by their children. To work issues of sexuality with their children from their inclusion in the school environment allows the formation of bonds between family-school. Through this it is possible to minimize anxieties, doubts and fears arising from children [9-11].

At another time nursing consultations were offered to people with mental disabilities. Such assistance aimed to understand health needs of the users an individualized way. The students, accompanied by teacher, performed qualified listening identifying the main concerns and questions related to sexuality. At this point the students sought to guide users, besides collaborating in the construction of new knowledge to become mental patients subjects active in health practices.

Thus, nursing consultation included history, physical examination, measurement of vital signs and assessment of laboratory tests. In addition, there were also relevant guidance on contraception, condoms, prevention of breast cancer and uterus as well as hygiene habits.

This action showed good results considering the lack of this population in health services, including in primary care. It explained this situation because of the needs presented often be accompanied by an isolated way by the institution in the absence of connection with primary care. The completion of the consultation provided the participation of nursing in the health/disease process of these subjects allowing the delineation of a new professional look.

Faced with the results presented, the students and the teacher developed a wheels of conversations with parents and health professionals of the institution. This activity-was guided in discussing how parents and professionals dealing with the sexuality of people with mental disabilities.

During the intervention professionals reported that discuss this issue is complex and delicate. However professionals agree that the theme needs to be worked through joint actions among family, 
school and health services. This is based on the concept of professionals understand the need for users of the institution to know and to talk about it. Nevertheless, even though this importance, there were obstacles in the institution to deal openly about sexual matters.

The family is seen as primarily responsible for the education of children, being the first to discuss sexuality issues. With this family influence in the formation of subjects, teaching them male and female characteristics through actions, attitudes and relationships established within the family nucleus [10].

The results of this educational practice are seen as satisfactory. That is because made it possible to observe the weaknesses of professionals to deal with the issues that permeate the lives of people with mental disabilities. Especially by addressing the issue sexuality, regarded by society as limiting for this group. This encouraged the students to identify the difficulties prevalent in professional practice.

Finally, a dynamic called "Box knowledge" was performed. This intervention was comprised of five boxes of different sizes one within the other and each of them discussed a different issue relating to sexuality. This action was intended to meet the care provided by parents, since it is essential that the family/caregiver is instrumented to take care of this clientele.

The first box contained figure of children, adults, toys and health professionals. The intention with these figures was to observe the relationship of the image that the parents had in relation to their children. This first activity was created in order to destigmatize childish look of the parents face their children, providing a moment of rediscovery of the body and emotional maturity.

This parental infantilization in relation to their children leads to overprotection. With this the opportunities for children to recognize their own skills and abilities are restricted. Once most activities are not allowed by their parents that interferes with the development of personality and common skills of children in daily life. Some parents see the care of their children as everything that should be avoided due to illness [12-13].

In the second box female and male dolls were used, addressing changes that occur on human body. It was intended to raise discussion about different needs of the person as a child and as an adult. From this it was had intended to alert that these needs are part of the construction of individuals.

Moreover, from this aimed to enhance the role of the family, the community in which the user is inserted, as partakers of the transformation of the mentally ill in a thinking, critical, opinion leader and participant of society individual. But the family by self-denial make care as exclusive of the family for fear of what other people's front people care process of these children can do with children. This conditions be social isolation of both and the restrictions on the common lifestyle [12-13].

In the third box it was offered a snack making analogy to physiological human needs such as the desire and the need to feed, as well as sexual desire. On the latter issue the intension was induce discussion of sexual desire and the desire to have someone around.

At this time there was dialogue where it was exposed to consider the libido is part of human needs. In this context, it was clarified that in the same way that there is the need to feed with food, there is also the need for affective relationships. Sexuality when understood and properly channeled, is translated into love, creativity, generating power of progress and development [14].

The fourth box brought a dynamic where parents would draw or write the importance and the meaning of love between people. From this concept it was proposed to the parents to make the relationship that their children should be loved not only for having a mental disability, but above all because they are human beings.

As results of this step, some parents designed hearts, the family who translated the meaning of love, and then they presented their designs. It is 
necessary to understand that the family is constituted by people of different personalities. Thus, it is essential to respect beliefs, cultures and different values of each person and family group. Therefore the family is included in the care and this improves the family relationship and acceptance of the disease15.

Finally, the fifth box was crafted with balloons. Participants were responsible for balloons within contained questions that approached: the imagination of parents to their own child, puberty, outside the family relationship, sexual desire and the act of masturbation. There was the moment that every one burst your balloon and answered your question that was discussed by the entire group. Thus it occurred interaction and exchange of knowledge in an attempt to demystify some stigmas, to ask questions and to warn about the use of contraceptive methods.

The use of this dynamic stimulated the participation of parents in discussions involving people with mental disabilities. This allowed reveal their feelings and views on the theme of sexuality. This intervention was deemed satisfactory because it allowed a reflection on the established relationships and how these relationships have been effective in improving the living conditions of users. Moreover, the dynamics allowed the verification the existence of dialogues about sexuality in this interaction.

Given these considerations, educational practices contribute to the inclusion of the university in a socially constructed reality. The participation of academia produces moments of reflection and questions about the work of professionals who seek to improve the living conditions of people. Thus, the nursing as a social practice has strengthened actions proposing the autonomy of the subjects in their health/disease process [16].

Activities like these have influenced the construction and enhanced know-how of nursing. In addition, they enrich the formation of graduates profile critically and emancipatory for pointing out principles for the organization of an expanded professional education. This occurs such that educational practices consider the specific characteristics of the various production units of health care, in particular an institution for people with physical and mental disabilities [17].

From this health education it was possible to observe the presence of stigmas among professionals to develop actions that contribute to the discussion of sexuality. Also, parents need of knowledge to discuss this issue with their children, as well as the deficiency is present as one more factor for the existence of such an obstacle. In turn, the users need basic knowledge about sexuality, being necessary to develop interventions to minimize this difficulty. In the context of all the members of this scenario investigated the social inclusion of these subjects is relevant and necessary for a more just society.

\section{Conclusion}

Health education actions seek to transform the existing reality to contribute to building knowledge and practices of users with mental disabilities from wheels of conversations and nursing consultation. These practices showed satisfactory results by encouraging discussion of issues related to sexuality present in the daily life of these subjects.

Parents and professionals were challenged to discuss sexuality in the lives of people with mental disabilities through wheels of conversations and dynamic being evident lack of knowledge and approach to work with the theme of sexuality. It is noteworthy stigma in discussing this issue in this family nucleus as well as in the institution.

So health education developed by students favored to minimize these gaps in the institution. Become indispensable activities involving the university with public institutions because it provides exchange of experiences, builds collaborative networks and sensitizes society. 
Thus, this educational practice collaborated on student formation to stimulate critical/reflective thinking and promoted social responsibility through knowledge building spaces. Besides having allowed the emancipation of the subject in their professionals practice in the perspective of collaborate in the transformation of an existing reality.

\section{References}

1. Zilioto GS, Marcolan JP. Percepção de trabalhadores de enfermagem sobre sexualidade de portadores de transtornos mentais. Acta paul enfermg. 2013; 26(1):86-92.

2. Souza PL, Pereira CS, Nogueira MLS, Pereira DB, Cunha GM, Moler FO. Projetos PET-Saúde e educando para a saúde: construindo saberes e práticas. Rev Bras Educ Med. 2012; 36(1): 172-177.

3. Moutinho CB, Almeida ER, Leite MTS, Vieira MA. Dificuldades, desafios e superações sobre educação em saúde na visão de enfermeiros de saúde da família. Trab educ saúde. 2014; 12(2):253-72.

4. Brasil. Resolução CNE/CES 3/2001 de 7 de novembro de 2001 Institui Diretrizes Curriculares Nacionais do Curso de Graduação em Enfermagem. Diário Oficial da União. [Internet]. 2001 [cited 2014 Aug 02]. Available from: http://portal.mec.gov.br/cne/ arquivos/pdf/CES03.pdf

5. Brasil. Ministério da Saúde. Fundação Nacional de Saúde. Oficinas de Educação em Saúde e Comunicação. [Internet]. 2001 [cited 2014 Aug 03]. Available from: http://www.funasa. gov.br/internet/

6. Brasil. Ministério da Saúde. Secretaria de Atenção à Saúde. Departamento de Ações Programáticas Estratégicas. Direitos sexuais, direitos reprodutivos e métodos anticoncepcionais. Brasília: Ministério da Saúde, 2006.

7. Freire, P. Pedagogia da autonomia: saberes necessários a prática educativa. São Paulo: Paz e Terra, 2011.

8. Belenzanni R, Santos AO, Paiva V. Agentes comunitárias de saúde e a atenção à saúde sexual e reprodutiva de jovens na estratégia saúde da família. Saúde Soc. 2012; 21(3):637-50.

9. Valli GP, Cogo ALP. Blogs escolares sobre sexualidade: estudo exploratório documental. Rev gaúcha enferm. 2013; 34(3):31-7.

10. Yano KM, Ribeiro MO. O desenvolvimento da sexualidade de crianças em situações de risco. Rev esc enferm USP. 2011; 45(6):1315-22.

11. Almeida SA, Nogueira JA, Silva AO, Torres GV. Orientação sexual nas escolas: fato ou anseio?. Rev gaúcha enferm. 2011; 32(1):107-13.
12. Silveira A, Neves ET, Paula CC. Cuidado familial das crianças com necessidades especiais de saúde: um processo (sobre)natural e de (super)proteção. Texto contexto - enferm. 2013 Out/Dez; 22(4):1106-1114

13. Silveira A, Neves ET. Crianças com necessidades especiais em saúde: cuidado familiar na preservação da vida. Cienc cuid saude 2012 jan/mar; 11(1):074-080.

14. Soares AN, Silveira BV, Reinaldo MAS. Oficinas de sexualidade em saúde mental: relato de experiência. Cogitare Enferm. 2010 Abr/Jun; 15(2):345-348.

15. Borba LO, Guimarães NA, Mazza VA, Maftum MA. Assistência em saúde mental sustentada no modelo psicossocial: narrativas de familiares e pessoas com transtorno mental. Rev Esc Enferm USP. 2012; 46(6):000-000

16. Cossetin A, Resta DG, Mattioni FC, Budó MLD. Educação popular em saúde no curso de graduação em enfermagem: construção de espaços curriculares participativos. Rev Enferm UFSM 2012; 2(3):560-568.

17. Azevedo IC, Vale LD, Araújo MG, Cassiano AN, Silva HS, Cavalcante RD. Sharing knowledge through health education in school: interfaces supervised nursing. R Enferm Cent O Min. 2014jan/abr; 4(1):1048-1056.

\section{Publish in International Archives of Medicine}

International Archives of Medicine is an open access journal publishing articles encompassing all aspects of medical science and clinical practice. IAM is considered a megajournal with independent sections on all areas of medicine. IAM is a really international journal with authors and board members from all around the world. The journal is widely indexed and classified Q1 in category Medicine. 